REVIEW

\title{
Patient Protection and Affordable Care Act of 2010: a primer for Neurolnterventionalists
}

\author{
Laxmaiah Manchikanti, ${ }^{1,2}$ Joshua A Hirsch ${ }^{3}$
}

${ }^{1}$ Pain Management Center of Paducah, Paducah, Kentucky, USA

${ }^{2}$ Department of Anesthesiology and Perioperative Medicine,

University of Louisville, Louisville, Kentucky, USA

${ }^{3}$ Department of

Neurolnterventional Radiology, Massachusetts General Hospital, Harvard Medical School, Boston, Massachusetts, USA

\section{Correspondence to}

Dr Laxmaiah Manchikanti, Pain

Management Center of Paducah, 2831 Lone Oak Road, Paducah, KY 42003, USA drlm@thepainmd.com

Disclosure: The manuscript is a brief version of Manchikanti L et al. Patient Protection and Affordable Care Act of 2010 reforming healthcare reform for the new decade. Pain Physician 2011;14:E35-E67. This version is published with the consent of all the authors and the permission of the journal Pain Physician.

Received 24 March 2011 Accepted 30 March 2011 Published Online First 27 April 2011

\section{ABSTRACT}

The Patient Protection and Affordable Care Act (the ACA, for short) became law on 23 March 2010. It represents the most significant transformation of the American healthcare system since Medicare and Medicaid. Essentials of ACA include: (1) a mandate for individuals and businesses requiring as a matter of law that nearly every American has an approved level of health insurance or pay a penalty; (2) a system of federal subsidies to completely or partially pay for the now required health insurance for $\sim 34$ million Americans who are currently uninsured-subsidized through Medicaid and Exchanges; (3) extensive new requirements on the health insurance industry and (4) changes in the practice of medicine. The Act is divided into 10 titles. It contains provisions that went into effect starting on 21 June 2010 with many of the provisions going into effect in 2014 and later. The ACA goes well beyond insurance and payment reform. Practicing physicians will potentially be impacted by the Independent Payment Advisory Board and the Patient Centered Outcomes Research Institute.

\section{INTRODUCTION}

On 23 March 2010, President Obama signed into law the most sweeping healthcare system reform legislation since Medicare was enacted in 1965. The debate has been both heated and divisive. There is a substantial literature that has emerged both in support of and in opposition to the Patient Protection and Affordable Care Act of 2010 (the ACA, for short). ${ }^{1-3}$

Supporters of the law maintain that the passage of comprehensive healthcare reform legislation presents tremendous opportunities to improve the way that America's healthcare system works. They believe that the reforms to expand coverage hold the potential to help millions of Americans. The opponents of the healthcare reform claim that ACA will transfer one-sixth of the US economy into the hands of politicians and agency bureaucrats.

Manchikanti et $a l^{3}$ recently published an article on the impact that the ACA will have on interventional pain management. There were elements of that review that would serve as useful background for NeuroInterventional specialists. For that reason, this brief communication was undertaken.

\section{ACA implementation}

The Act is divided into 10 titles. It contains provisions that went into effect starting on 21 June
2010, with the majority of the provisions going into effect in 2014 and later (table 1). ${ }^{4}$

\section{ESSENTIALS OF ACA}

Essentials of ACA have been described in multiple publications, many of them partisan and opinion based. We endeavor to present the facts while limiting our commentary.

There are charges for those who fail to buy health insurance and a penalty on employers above a certain size who do not cover their employees The Internal Revenue Service is the agency charged with enforcement. Those penalties on individuals, after a brief start-up period, are $\$ 695$ annually for each individual (limited to three times that amount for any family) or $2.5 \%$ of income, whichever is greater. An individual without the required insurance and with an income of $\$ 20000$ pays a tax of $\$ 695$; at $\$ 50000$ the tax is $\$ 1250$; at $\$ 100000$ it is $\$ 2500$. $^{2}$

The ACA establishes a system of subsidies for the purchase of health insurance that are based primarily on income and family size.

The first subsidy is an expansion of the existing Medicaid program to include every American whose income is under ' $133 \%$ or $138 \%$ of poverty'. In practical terms, in 2014, when Medicaid expansion takes place, individuals with incomes less than $\sim \$ 15800$ or families of four with incomes less than $\sim \$ 32300$ will become eligible for comprehensive, affordable health insurance.

Under ACA, there will be a new national uniform income qualification-having an income below the ' $133 \%$ or $138 \%$ of poverty' level-and there is no longer any requirement to spend other assets or to belong to a covered category. This expansion of Medicaid eligibility is expected to provide health insurance to $\sim 18$ million additional Americans by $2019{ }^{2}$

The second of these subsidies is an extensive cost-sharing arrangement for health insurance purchased through new 'Exchanges'. The Exchanges are designed to be state-run administrations that will organize and approve heath insurance plans being sold by the insurance industry and present those plans accurately and in place as a form of 'one-stop shopping'. The health insurance offered through these Exchanges is primarily available to those without employer-provided health insurance. These subsidies are available to Americans whose income is up to ' $400 \%$ of poverty' (\$93700 for a family of four in 2014 ). At ' $133 \%$ or $138 \%$ of poverty', an individual is responsible for the cost of health insurance up to a level of $2 \%$ of 
Table 1 Implementation schedule of ACA

\begin{tabular}{|c|c|c|}
\hline Issue & What legislation would do & Effective date \\
\hline \multicolumn{3}{|l|}{2010} \\
\hline Business tax credits & $\begin{array}{l}\text { Small businesses with no more than } 25 \text { employees and average annual wages of } \\
\$ 40000 \text { would receive tax credits to help provide insurance to employees. The tax } \\
\text { credit would be up to } 35 \% \text { of the employer's contribution if the employer pays } 50 \% \\
\text { of the total premium cost. }\end{array}$ & $\begin{array}{l}2010 \text { tax year, with the c } \\
\text { increasing up to } 50 \% \text { in } 2\end{array}$ \\
\hline Temporary reinsurance program & $\begin{array}{l}\text { A } \$ 5 \text { billion temporary reinsurance program would be created for employees to } \\
\text { provide healthcare coverage for retirees over the age of } 55 \text { who are not eligible for } \\
\text { Medicare. }\end{array}$ & 90 days after enactment \\
\hline Temporary high-risk insurance pool & $\begin{array}{l}\text { A } \$ 5 \text { billion temporary national high-risk insurance pool would be created to provide } \\
\text { health coverage to individuals with pre-existing medical conditions who have been } \\
\text { uninsured for at least } 6 \text { months. }\end{array}$ & 90 days after enactment \\
\hline Pre-existing conditions & $\begin{array}{l}\text { Insurance companies would be barred from denying coverage to children who have } \\
\text { pre-existing medical conditions. }\end{array}$ & 6 months after enactmen \\
\hline Adult dependent children & $\begin{array}{l}\text { Insurance companies would have to provide coverage for dependent children up to } \\
\text { the age of } 26 \text {. }\end{array}$ & 6 months after enactmen \\
\hline Insurance coverage limits & $\begin{array}{l}\text { Insurance plans would be prohibited from placing lifetime limits on how much they } \\
\text { pay out to individual policyholders and from rescinding coverage except in cases of } \\
\text { fraud. }\end{array}$ & 6 months after enactmen \\
\hline Medicare drug rebates & $\begin{array}{l}\text { Medicare patients who face a gap in prescription drug coverage would receive } \\
\text { a 1-year, } \$ 250 \text { rebate to help pay for medication. }\end{array}$ & Immediately \\
\hline Tanning salon tax & A tax of $10 \%$ would be imposed on the cost of indoor tanning services. & Immediately \\
\hline Preventive services & Health insurance plans would be required to cover preventive services such as & 6 months after enactme \\
\hline
\end{tabular}

2011 immunization for children and cancer screenings for women.

The federal tax on individuals who spend money from heathcare savings accounts on ineligible medical expenses would double to $20 \%$.

Funding would increase by $\$ 11$ billion for community health centers that provide medical care to patients who can not afford it.

Drug companies would provide a $50 \%$ discount on brand-name prescription drugs for seniors who face a gap in drug coverage. More subsidies would be phased in through 2020, when the coverage gap would be closed.

Primary care

Primary care doctors and general surgeons practicing in areas that lack primary care doctors would receive a $10 \%$ bonus payment under Medicare.

Long-term care

A voluntary long-term care program called CLASS* would be created. After at least 5 years of contributions, enrollees would be entitled to a $\$ 50$-a-day cash benefit to pay for long-term care.

New annual fee on drug-makers

A total annual fee of $\$ 2.5$ billion would be imposed on pharmaceutical manufacturers.

Insurance rebates

Health insurance companies would be required to provide rebates to enrollees if they spend $<85 \%$ of their premium dollars on healthcare as opposed to administrative costs.

\section{2-2013}

Annual fee on drug-makers

Contribution limits on healthcare savings accounts

Itemized deductions for unreimbursed medical expenses

Medicare taxes

\section{4}

Individual mandate

Employer requirements

Medicaid expansion

Federal subsidies

Annual fee on insurance companies Health insurance Exchanges

2015-2016

Individual mandate

Annual fee on insurance companies
The annual fee on pharmaceutical manufacturers would increase to $\$ 3$ billion each year through 2016 .

The limit on how much individuals could contribute to flexible savings accounts that let people set aside money tax free for health costs would be set at $\$ 2500$. Currently employers set the limit.

The threshold for deducting such expenses would increase from $7.5 \%$ of adjusted gross income to $10 \%$.

The Medicare tax rate would increase by 0.9 percentage points-from $1.45 \%$ to $2.35 \%$ - on earnings over $\$ 200000$ for individuals and $\$ 250000$ for families. Also, for the first time, a 3.8\% Medicare tax would be imposed on unearned income.

Most Americans would be required to buy health insurance or pay fines of $\$ 95$ per individual up to $\$ 285$ per family or $1 \%$ of taxable household income, whichever is greater.

Companies with $\geq 50$ employees would pay a fine if any of their full-time workers qualified for federal healthcare subsidies.

The program for low-income Americans under the age of 65 would expand by increasing the income eligibility to $133 \%$ of federal poverty, or $\$ 29327$ for a family of four.

Federal subsidies, which vary based on household income, would help offset the cost of buying insurance for Americans and legal residents who qualify.

An annual fee totaling $\$ 8$ billion would be imposed on heath insurance companies.

A state-based healthcare Exchange-a marketplace where uninsured individuals and small businesses could comparison shop for insurance policies-would be created.

Penalties for not carrying insurance would increase to $\$ 325$ for each family member up to $\$ 975$ per family or $2 \%$ of taxable household income, whichever is greater. The annual fee on health insurance companies would increase to $\$ 11.3$ billion.
1 October 2011

1 January 2011

1 January 2011 through 2015

1 January 2011

1 January 2011

1 January 2011

1 January 2012

1 January 2013

1 January 2013

1 January 2013

1 January 2014

1 January 2014

1 January 2014

1 January 2014

1 January 2014

1 January 2014

1 January 2015

1 January 2015 
Table 1 Continued

\begin{tabular}{ll}
\hline Issue & What legislation would do \\
\hline \multicolumn{1}{|l}{ Individual mandate } & $\begin{array}{l}\text { Penalties for not carrying insurance would increase to } \$ 695 \text { for each family member } \\
\text { up to } \$ 2085 \text { per family or } 2.5 \% \text { of taxable household income, whichever is greater. }\end{array}$ \\
$2017-2018$ & $\begin{array}{l}\text { The annual fee on pharmaceutical manufacturers would increase to } \$ 3.5 \text { billion } \\
\text { in } 2017 \text { and } \$ 4.2 \text { billion in } 2018 .\end{array}$ \\
Annual fee on drug-makers & $\begin{array}{l}\text { The annual fee on health insurance companies would increase to } \$ 13.9 \text { billion } \\
\text { in } 2017 \text { and } \$ 14.3 \text { billion in } 2018 .\end{array}$ \\
Annual fee on insurance companies & A $40 \%$ excise tax would be imposed on healthcare plans that cost more than \\
Excise tax on high-cost insurance plans & $\$ 10200$ for individual coverage and $\$ 27500$ for family coverage.
\end{tabular}

*Community Living Assistance Services and Support.

Source: Kaiser Family Foundation, White House, The Commonwealth Fund.

their income. For incomes above this level, the maximum percentage of income that anyone should have to pay increases in steps to $9.5 \%$ of income at ' $400 \%$ of poverty'. Table 2 provides examples of cost of insurance and contributions. ${ }^{5}$

The third subsidy consists of temporary (2-year) tax credits to small businesses as an incentive to begin offering health insurance. The credit can be up to $50 \%$ of the employer's contribution in businesses with fewer than 10 employees and an average wage under $\$ 25000$. There is no legal mandate for employers to offer insurance; however, there are penalties for employers of $>50$ persons who do not offer insurance or whose insurance places too much of the cost on the employee, which vary from $\$ 2000-\$ 3000$. These anticipated penalties are a substantial source of the revenue that is used to pay for the ACA. ${ }^{2}$

The ACA enacted a set of new insurance industry requirements. The ACA requires insurers to issue policies to anyone qualified who applies, to renew policies without regard to the health status of the insured, to eliminate pre-existing condition limitations and to require that rates in the Exchange and small group markets vary only based on age, the geographic area, family composition and tobacco use, thus reducing adverse selection. ${ }^{2}$ There are other requirements on the insurance industry including at least $85 \%$ of the premiums they collect from large groups to be spent for medical care.

\section{IMPACT ON HEALTHCARE SPENDING}

According to Congressional Budget Office (CBO) estimates, the number uninsured will be reduced by 32 million from the current level of 50 million. Despite this seemingly impressive

Table 2 Exchange cost sharing 2014

\begin{tabular}{lllllll}
\hline \multicolumn{2}{l}{ Family income } & \multicolumn{3}{l}{ Cost of insurance } \\
\cline { 1 - 2 } \cline { 5 - 6 } Amount & $\begin{array}{l}\text { Percentage } \\
\text { of poverty }\end{array}$ & & $\begin{array}{l}\text { Total } \\
\text { cost }\end{array}$ & $\begin{array}{l}\text { Individual } \\
\text { cost }\end{array}$ & $\begin{array}{l}\text { Federal } \\
\text { subsidy }\end{array}$ & $\begin{array}{l}\text { Subsidy } \\
\text { per cent of total }\end{array}$ \\
\hline$\$ 30000^{*}$ & 128 & $\$ 19300$ & 0 & $\$ 19300$ & 100 \\
$\$ 40000$ & 171 & $\$ 14245$ & $\$ 1982$ & $\$ 12263$ & 86 \\
$\$ 50000$ & 213 & $\$ 14245$ & $\$ 3385$ & $\$ 10860$ & 76 \\
$\$ 60000$ & 256 & $\$ 14245$ & $\$ 4937$ & $\$ 9308$ & 65 \\
$\$ 70000$ & 299 & $\$ 14245$ & $\$ 6626$ & $\$ 7619$ & 53 \\
$\$ 80000$ & 342 & $\$ 14245$ & $\$ 7600$ & $\$ 6645$ & 47 \\
$\$ 90000$ & 384 & $\$ 14245$ & $\$ 8550$ & $\$ 5695$ & 40 \\
$\$ 100000$ & 427 & $\$ 14245$ & $\$ 12245$ & 0 & 0
\end{tabular}

*A family with an income of $\$ 30000$ would qualify for Medicaid, which is not directly comparable with the Exchange polices. It would not typically have a premium cost and outof-pocket costs vary by state. This figure is an estimate based on Medicaid having a value of $95 \%$ of the total cost of healthcare.

Source: Kaiser Family Foundation 'Health Reform Subsidy Calculator' (http://healthreform. kff.org/SubsidyCalculator.aspx $)^{5}$

Note: Based on purchase of the 'silver' plan ( $70 \%$ actuarial value): family of 4 , 45 -year-old policyholder, medium cost area, health insurance policy cost of $\$ 14245$ (estimated by Kaiser) in 2014. number it will leave 23 million residents without health insurance in 2019 after the Act is fully implemented. ${ }^{6}{ }^{7}$ It is also estimated that private insurance enrollment will rise steeply as a projected 15.8 million obtain coverage through health insurance Exchange plans in $2014 .^{8}$

Provisions to expand coverage under the ACA will not affect large numbers of Americans until 2014. In the interim, it is likely that employer-sponsored insurance will continue to decline because premiums will almost certainly grow faster than wages and salaries, ${ }^{7}$ and the number of uninsured people is likely to increase.

After 2014, self-employed Americans and most workers in small firms will be allowed to purchase coverage through insurance Exchanges. The Medicaid expansion will add comprehensive coverage at little or no cost for the lowestincome adults with help to solidify the safety net and prevent the erosion of coverage among adults in future economic downturns.

In dealing with those who are privately insured, there is substantial debate on the impact of the ACA on premiums. While the administration officials have said that there will be reduction in premiums of $\$ 2500$ for each individual, ${ }^{9}$ others have estimated that these premiums will increase significantly. However, the Office of the Actuary at the Centers for Medicare and Medicaid Services (CMS) in their report released in April 2010 projected that ACA would increase the number of Americans with health insurance coverage but would also increase projected spending by $\sim 1 \%$ over a period of 10 years. ${ }^{10}$

Per the authors of the law, the ACA includes a series of Medicare reforms that will generate billions of dollars in savings for Medicare and strengthen the care Medicare beneficiaries receive. ${ }^{11}$ In addition, the Medicare Hospital Insurance Trust Fund is increased by 12 years, more than doubling the time before the exhaustion of the trust fund. ${ }^{12} \mathrm{CMS}$ also noted that, historically, Medicare has often led the entire healthcare system in the adoption of quality and payment innovation. Consequently, they claim that the ACA ensures that Medicare will continue to serve as a leader in driving the widespread adoption of innovative quality and payment strategies.

Based on their claims of the savings, the law's authors have projected Medicare's fiscal outlook, both with and without passage of ACA. According to their calculations, by 2019 Medicare spending will grow by $6.8 \%$, reaching $\$ 978$ billion; with reform, spending will grow $5.3 \%$, reaching $\$ 852$ billion (figure 1).

Further, Foster, ${ }^{13}$ Chief Actuary of CMS, in his analysis accompanying the Annual Report of the Medicare Board of Trustees, noted that Medicare per assumptions of the ACA, predicts that payment rates for doctors and hospitals serving seniors will be cut by $30 \%$ over the next 3 years. While the ACA, as amended, makes important changes to the Medicare program 


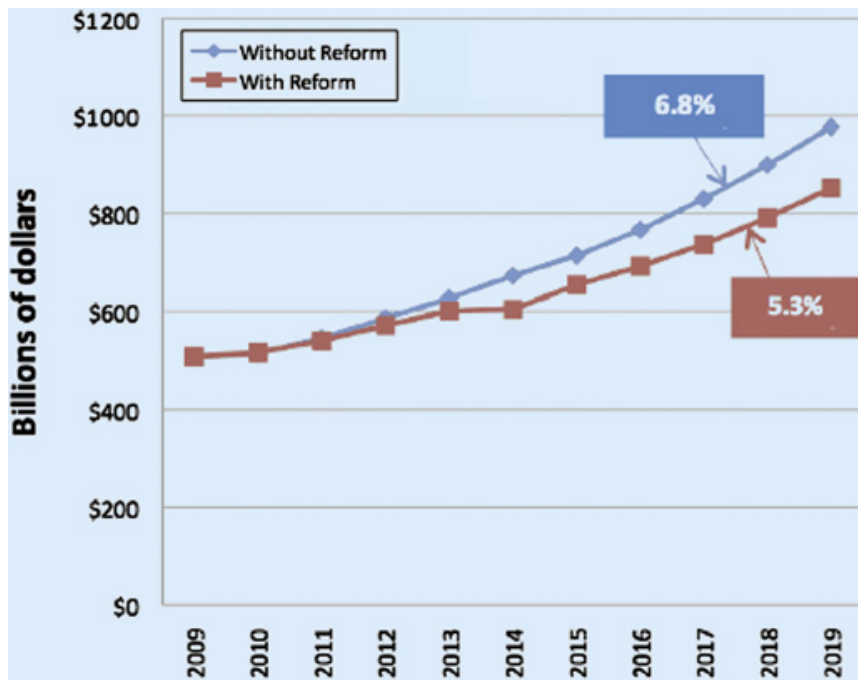

Figure 1 Projected Medicare fiscal outlook.

and substantially improves its financial outlook, there is a strong likelihood that certain of these changes will not be viable in the long range. He further reported that, specifically, the annual price updates for most categories of non-physician health services will be adjusted downward each year by the growth in economy-wide productivity. The best available evidence indicates that most healthcare providers cannot improve their productivity to this degree-or even approach such a level-as a result of the labor-intensive nature of these services.

Medicare Advantage Plans will have a significant impact on the Medicare budget and seniors. ${ }^{14} 15$ Medicare payments to plans are estimated to total $\$ 116$ billion in 2010, accounting for $22 \%$ of total Medicare spending. The ACA reduces the federal payments to Medicare Advantage Plans over time, bringing them closer to the average costs of care under the fee-for-service Medicare program. The law also provides new quality bonus payments to plans, beginning 2012, and beginning in 2014, will require plans to maintain a medical loss ratio of at least $85 \%$, restricting the share of premiums that Medicare Advantage firms can use for administrative expenses and profits.

Estimates from the CBO suggest that Medicaid will add 16 million enrollees, $50 \%$ of the expected 32 million, to Medicaid. The expanded coverage will be free to the states at least through 2016 and to uninsured persons whose income qualifies them for it. That having been said, it is well known that eligibility for health insurance does not always translate into actual enrollment-as evidenced by the millions of uninsured adults who are already eligible for Medicaid under current law. ${ }^{16}$

There are multiple other regulations impacting Medicare and Medicaid in the healthcare law. One such is the 15-member Independent Payment Advisory Board (IPAB) whose task is to make recommendations to reduce the per capita growth rate in Medicare spending. ${ }^{17}$ Another law having an affect is the Physician Quality Reporting Initiative, or PORI. ${ }^{18}$

Under ACA, CMS officials will also be charged with designing 20 new payment systems for physicians. The statute specifically calls for the reduction of Medicare payment away from traditional fee-for-service, which serves $\sim 77 \%$ of seniors today, in favor of salaried physician payments. ${ }^{19}$ One of the challenges in evaluating the ACA involves cost estimates related to the sustainable growth rate (SGR) formula. Relying on statutory corrections and temporary doctors fixes, most observers agree that this system requires updating. As it remains the current system presently, it has been utilized for savings and deficit reduction measures in affordable healthcare law cost estimations and savings. Beyond methodological challenges, there are issues with the use of the SGR system in these calculations, that is, a system that most observers agree needs to be reformed.

\section{ADMINISTRATIVE SPENDING AND REGULATIONS}

Regulatory reform is a part of the ACA. To put the size of the existing regulatory regime into perspective, Conover, ${ }^{20}$ estimated that the net cost of health services regulation was $\$ 169.1$ billion annually in 2004.

In October 2009, a Thomson-Reuters report stated that the healthcare system wastes between $\$ 505$ billion and $\$ 850$ billion every year, an estimated one-third of the nation's healthcare bill. ${ }^{21}$ This report indicates that healthcare waste can be attacked and healthcare costs can be reduced without adversely affecting the quality of access of care. This report shows that elimination of paper-based medical record systems will save $6 \%$ of the spending.

\section{IMPACT ON PRACTICE OF MEDICINE}

The ACA will make health insurance available to an additional 34 million Americans. ${ }^{2}$ However, while insurance may be provided, the coverage for many procedures may be either diminished or eliminated. There are well over 100 sections of the law dealing with various aspects of the Medicare programs including some reduction in payments for physician services.

The Congressional Research Service in its 21 April 2010 report $^{22}$ observed that the law makes several changes to the Medicaid program that have the potential to affect physicians and how they practice. The report also adds that while some of the provisions have clear and direct consequences, for instance, altering physician reimbursement right away, others have the potential to influence how physicians might practice in the future by changing the incentives to encourage improvements in the organization and delivery of care.

\section{Independent Payment Advisory Board}

The IPAB is based on the philosophy that there is a need for a board of impartial experts to oversee the healthcare system. The legislation established specific target growth rates for Medicare and charges the IPAB with ensuring that Medicare expenditures stay within these limits. The IPAB must also make recommendations to Congress as to how to control healthcare costs. The IPAB will have 15 members appointed by the President for a 6-year term, supplemented by three officials representing the Department of Health and Human Services (DHHS). IPAB members are supposed to be nationally recognized experts in health finance, payment, economics, actuarial science, or health facility and heath plan management, and to represent providers, consumers and payers. The ACA appropriated $\$ 15$ million for the IPAB for 2012 and increases its funding at the rate of inflation for subsequent years. The purpose of the IPAB is to reduce the per capita rate of growth in Medicare spending indefinitely. It should be noted that in most years Medicare's per capita growth has been below or equal to growth in the private sector. There is no congressional authority over this board. The $\mathrm{CBO}$ concluded in its analysis of the ACA that the IPAB would reduce Medicare spending by $\$ 28$ billion over the period 2010-2019, with significant savings continuing beyond 2019.

Many questions remain about how the IPAB will work. The relationships between the IPAB and other boards and commissions, such as the MedPAC and the Centers for Medicare and Medicaid Innovation created by the ACA, has not been 
determined. Its success also will depend on Congress's reactions to its recommendations. A $3 / 5$ senate vote will be needed to override payment cuts, but Congress could increase Medicare funding through independent legislation. Proposals for years before 2020 may not target inpatient or outpatient acute hospitals, long-term care hospitals, inpatient rehabilitation hospitals, psychiatric hospitals and possibly hospice care prior to 2020. However, the board is not prohibited from cutting payments for physicians, though its powers may be limited if a permanent fix for the SGR formula is passed. Table 3 illustrates a 3 -year time horizon for IPAB proposals. ${ }^{123}$

\section{PATIENT CENTERED OUTCOMES RESEARCH INSTITUTE}

The Patient Centered Outcomes Research Institute (PCORI) focuses on comparative effectiveness research and provides impressions about the effectiveness of various modalities. It cannot be used for denial of coverage. PCORI is similar to the National Institute for Health and Clinical Excellence in the $\mathrm{UK}^{24}{ }^{25}$ Interestingly, the role of the National Institute for Health and Clinical Excellence in the National Health Service, which is highly proscriptive, has been questioned and the National Health Service is attempting to empower practicing physicians. $^{26-28}$

\section{COST CONTROLS}

Controlling the cost of healthcare is a major motivator for supporters of the ACA. They state that the projections suggest that with reform, total healthcare expenditure as a percentage of the gross domestic product will be $0.5 \%$ lower in 2030 than it would otherwise have been. Indeed, the commonwealth fund projected that expenditure for the whole healthcare system will be reduced by nearly $\$ 600$ billion in the first decade. ${ }^{29}$

Table 3 Three-year sequence of events

\begin{tabular}{|c|c|}
\hline \multicolumn{2}{|l|}{ Determination year } \\
\hline By 30 April & $\begin{array}{l}\text { Chief Actuary of CMS makes projections and } \\
\text { determination }\end{array}$ \\
\hline By 1 September & $\begin{array}{l}\text { Draft proposal sent by IPAB to MedPAC for } \\
\text { consultation. Draft proposal sent by IPAB to Secretary } \\
\text { for review and comment }\end{array}$ \\
\hline \multicolumn{2}{|l|}{ Proposal year } \\
\hline By 15 January & $\begin{array}{l}\text { Proposal submitted by IPAB to Congress and the } \\
\text { President }\end{array}$ \\
\hline By 25 January & $\begin{array}{l}\text { Secretary submits own proposal to Congress and the } \\
\text { President, with a copy to MedPAC, if IPAB was } \\
\text { required to submit a proposal but failed to do so }\end{array}$ \\
\hline By 1 March & $\begin{array}{l}\text { Secretary submits report containing review and } \\
\text { comments to Congress on IPAB proposal (unless the } \\
\text { Secretary submitted own proposal because IPAB failed } \\
\text { to do so) }\end{array}$ \\
\hline By 1 April & $\begin{array}{l}\text { Deadline for specified congressional committees to } \\
\text { consider the submitted proposal and report out } \\
\text { legislative language implementing the } \\
\text { recommendations. Congress has the authority to } \\
\text { develop its own proposal provided it meets the same } \\
\text { fiscal requirements as established for the IPAB and } \\
\text { meets this deadline. }\end{array}$ \\
\hline Beginning 15 August & $\begin{array}{l}\text { Secretary implements the proposal subject to } \\
\text { exceptions }\end{array}$ \\
\hline On 1 October & $\begin{array}{l}\text { Recommendations relating to fiscal year payment rate } \\
\text { changes take effect }\end{array}$ \\
\hline \multicolumn{2}{|l|}{ Implementation year } \\
\hline On 1 January & $\begin{array}{l}\text { Recommendations relating to Medicare Part } C \text { and } D \\
\text { payments take effect. Recommendations relating to } \\
\text { calendar year payment rate changes take effect }\end{array}$ \\
\hline
\end{tabular}

IPAB, Independent Payment Advisory Board.

Source: CRS analysis of P.L. 111-148 as amended.
The $\mathrm{CBO}$, in its scoring of the ACA, considered that one of the significant ways of paying for expanding health insurance coverage was the use of premiums from the new Community Living Assistance Services and Support (CLASS) Act Entitlement. In this proposal, the legislation begins collecting premiums for this insurance in 2015, but does not begin paying out benefits until 2020, which is outside of the CBO 10-year time horizon. $^{1-3}$ The $\mathrm{CBO}$ scoring of the legislation takes those first 5 years of premiums and drives them to pay for its expansion and coverage. The diversion represents $\$ 70$ billion of the offsets to the costs of the legislation. It also assumes that when it becomes necessary to begin paying benefits in 2020, there will be other premiums from other Americans to cover the cost. The second issue is related to the credit of $\$ 198$ billion savings from reducing Medicare provider rates in future years. This is widely opposed by the physician community and has never been realized in the past. ${ }^{1-3} 3031$

\section{Health insurance premiums}

Several health insurers stated that they are seeking rate increases as a direct result of the law or unrelated to ACA. ${ }^{32-34}$ The rate increases also apply mostly to employees of small businesses of fewer than 50 people and to people who buy plans as individuals. It has been estimated that some customers could experience rate increases of $>20 \%$. ${ }^{35}$ However, the administration stated that insurers had already planned to raise rates and were using the Bill as an excuse. In addition, some insurance companies also announced that in response to the law, they would end the issuance of new child-only policies.

The DHHS informed that health insurers that raise premiums by $\geq 10 \%$ will face new regulatory scrutiny. Under the guidelines, which are preliminary, insurers would have to post detailed justifications online when the proposed double-digit rate hikes are introduced. The rules also define more clearly how regulators should ascertain whether a rate increase is reasonable.

The issue of enrollment of persons with pre-existing conditions is one of the most important achievements of ACA. However, the data show that only 8000 have enrolled in a health plan for pre-existing conditions as of 1 November 2010. Almost 6 million Americans are potentially eligible for the program, which runs through 2013. The $\$ 5$ billion in federal funding designated by the law may not be enough to cover all eligible individuals and the $\mathrm{CBO}$ projects that enrollment will average 200000 a year between 2011 and 2013.

\section{State opt-outs}

Beginning 2017, opt-out provision in the health reform law allows states to request federal waivers to be exempted from certain requirements in the law. As an example, states could opt out of the law's requirements for mandatory coverage, health insurance Exchanges and penalties for employers that do not provide coverage. ${ }^{2}$ However, states must first revise a coverage program that is at least as comprehensive and affordable as the health reform law, as judged by Secretaries of DHHS as well as the Treasury.

\section{Medical loss ratios}

The DHHS issued final regulations on 22 November 2010 on what health insurers must do to meet the medical-loss ratio requirement as part of the new health system reform law. Starting in January 2011, if health plans do not spend enough of their premium dollars on medical care and quality improvement, they must provide a rebate to customers in 2012. Further, insurers will need to report publically how they spend premium dollars 
beginning next year. The regulations also specify that insurance companies in the individual and small group markets need to spend at least $80 \%$ of the premium dollars they collect on medical care and quality improvement activities whereas those in the large group market must spend at least $85 \%$. DHHS believes that these new rules based on ACA are an important step to hold insurance companies accountable and increase value for consumers. DHHS officials believe that the regulations will help reign in a substantial portion of insurance company spending on services unrelated to medical care, such as executive salaries, underwriting, marketing, advertising and other administrative costs. It is believed that these overhead costs contribute little or nothing to the care of patients and the health of consumers.

\section{CONCLUSION}

The ACA is historic and produces legislative changes to healthcare greater than any that many US-based doctors have experienced in their lifetime. NeuroInterventionalists, as well as other providers, should be familiar with this legislation as it will likely have impact on their practice.

Acknowledgments We would like to thank Pain Physician for providing permission to publish in an abbreviated form.

Competing interests None.

Provenance and peer review Not commissioned; internally peer reviewed.

\section{REFERENCES}

1. Public Law No: 111-148: H.R. 3590. Patient Protection and Affordable Care Act March 23, 2010

2. Bredesen P. Fresh Medicine: How to Fix Reform and Build a Sustainable Health Care System. 1st edn. New York: Atlantic Monthly Press, 2010.

3. Manchikanti L, Caraway DL, Parr AT, et al. Patient Protection and Affordable Care Act of 2010: reforming health care reform for the new decade. Pain Physician 2011;14:E35-67

4. Affordable Health Care for America. Health insurance reform at a glance: implementation timeline. http://docs.house.gov/energycommerce/TIMELINE.pdf.

5. Kaiser Family Foundation. 'Health Reform Subsidy Calculator'. http://healthreform. kff.org/SubsidyCalculator.aspx.

6. Trumbull M. Obama Signs Health Care Bill: Who Won't be Covered? Christian Science Monitor, 2010. http://www.csmonitor.com/USA/2010/0323/Obama-signshealth-care-bill-Who-won-t-be-covered.

7. Kronick R, Gilmer T. Explaining the decline in health insurance coverage, 1979-1995. Health Aff (Millwood) 1999;18:30-47.

8. Sisko AM, Truffer CJ, Keehan SP, et al. National health spending projections: the estimated impact of reform through 2019. Health Aff (Millwood) 2010;29:1933-41.

9. Farley R. Obama Says Health Reform Legislation Could Reduce Costs In Employer Plans By Up To \$3,000. PolitiFact (St Petersburg Times), 2010. http://www.politifact. com/truth-o-meter/statements/2010/mar/19/barack-obama/obama-says-healthreform-legislation-could-reduce-/.

10. Alonso-Zaldivar R. Report Says Health Care Will Cover More, Cost More: Mixed Review for New Health Care Law Says Covering More Still Comes with Greater Costs. Associated Press, 2010. http://abcnews.go.com/Business/wireStory? id $=10454567$ gtqkw $=$ gtqshow $=$

11. Fact Sheet: The Affordable Care Act's New Patient's Bill of Rights. http://www. healthcare.gov/law/provisions/billofright/patient bill of rights.html.
12. Affordable Care Act Update: Implementing Medicare Cost Savings. CMS Office of the Actuary, 2010. http://www.cms.gov/apps/docs/ACA-Update-ImplementingMedicare-Costs-Savings.pdf.

13. Statement of Actuarial Opinion from Richard S. Foster, Chief Actuary of the Department of Health and Human Services RE: 2010 Annual Report of the Boards of Trustees of the Federal Hospital Insurance and Federal Supplementary Medical Insurance Trust Funds. Washington, DC, 2010. http://www.cms.gov/ ReportsTrustFunds/downloads/tr2010.pdf.

14. H.R. 2015. Balanced Budget Act of 1997, P.L. 105-33. August 5, 1997.

15. H.R. 1. The Medicare Prescription Drug, Improvement, and Modernization Act of 2003, P.L. 108-173. Enacted December 8, 2003

16. Sommers BD, Epstein AM. Medicaid expansion-the soft underbelly of health care reform? N Engl J Med 2010;363:2085-7.

17. Moffit RE. Doctors, patients, and the new Medicare provisions. Heritage Foundation December 14, 2009. http://www.heritage.org/Research/Lecture/2010/12/DoctorsPatients-and-the-New-Medicare-Provisions.

18. Centers for Medicare and Medicaid Services. 2010 Physician Quality Reporting Initiative Implementation Guide. Version 4.1. 2010. https://www.cms.gov/PQRI/ Downloads/2010 PORI ImplementationGuide 02-10-2010 FINAL.pdf.

19. DiGiovanni C, Moffit $\overline{\mathrm{R}} \mathrm{E}$. How Obamacare Empowers the Medicare Bureaucracy: What Seniors and Their Doctors Should Know. Heritage Foundation WebMemo No. 2989, August 24, 2010. http://www.heritage.org/Research/Reports/2010/08/HowObamacare-Empowers-the-Medicare-Bureaucracy-What-Seniors-and-Their-DoctorsShould-Know.

20. Conover CJ. Health Care Regulation: A \$169 Billion Hidden Treatment. Washington, DC: CATO Institute, 2004. Policy Analysis No. 527.

21. Fox M. Healthcare System Wastes Up To $\$ 800$ Billion a Year. Reuters, 2009. http:// www.reuters.com/article/idUSTRE59P0L320091026.

22. Davis PA, Hahn J, Morgan PC, et al. Medicare Provisions in PPACA (P.L. 111-148) Congressional Research Service Report for Congress, 2010. http://healthcarereform procon.org/sourcefiles/CRS Medicaid Provisions HR3590.pdf.

23. Newman D, Davis CM. The Indepeñdent Payment Advisory Board. Congressional Research Service Report for Congress, 2010. http://assets.opencrs.com/rpts/ R41511 20101130.pdf.

24. Patient-Centered Outcomes Research Institute (PCORI). United States Government Accountability Office. http://www.gao.gov/about/hcac/patientcentered outcomes. html.

25. Manchikanti L, Falco FJ, Boswell MV, et al. Facts, fallacies, and politics of comparative effectiveness research: Part 2. Implications for interventional pain management. Pain Physician 2010;13:E55-79.

26. Black N. 'Liberating the NHS'-another attempt to implement market forces in English health care. N Engl J Med 2010;363:1103-5

27. Hughes G. Nice or not so nice? Emerg Med J 2011;28:90

28. Timimi S, Jureidini J, Leo J. NICE guidance on ADHD. NICE recommendations are not evidence based and could expose many to unnecessary harm. BMJ 2008;337:a2284.

29. Cutler DM, Davis K, Stremikis K. The impact of health reform on health system spending. Issue Brief (Commonw Fund) 2010;88:1-14.

30. Manchikanti L, Singh V, Boswell MV. Interventional pain management at crossroads: the perfect storm brewing for a new decade of challenges. Pain Physician 2010;13:E111-40.

31. Medicare Payment Advisory Commission. Report to the Congress: Medicare Payment Policy. Washington, DC: Medicare Payment Advisory Commission, 2010.

32. Blase B, Hederman RS. Obamacare Increases Health Insurance Premiums. Heritage Foundation, 2010. http://thf media.s3.amazonaws.com/2010/pdf/ wm3021.pdf.

33. Ellis RP, Albert Ma CT. Health insurance, cost expectations, and adverse job turnover. Health Econ 2011;20:27-44.

34. New Affordable Care Act Rules Shed Light on High Health Insurance Rate Hikes. US Department of Health and Human Services, 2010. http://www.hhs.gov/news/press/ 2010pres/12/20101221a.html.

35. Adamy J. Health insurers plan hikes. Wall Street Journal 2010. http://online.wsj. com/article/SB10001424052748703720004575478200948908976.html? mod=WSJ hpp MIDDLETopStories. 